\title{
Importance of Ferritin for Optimizing Anemia Therapy in Chronic Kidney Disease
}

\author{
Takeshi Nakanishi Takahiro Kuragano Masayoshi Nanami Yoshinaga Otaki \\ Hiroshi Nonoguchi Yukiko Hasuike \\ Department of Internal Medicine, Division of Kidney and Dialysis, Hyogo College of Medicine, \\ Nishinomiya, Japan
}

\section{Key Words}

Ferritin - Maintenance hemodialysis - Anemia of chronic disease

\begin{abstract}
The clinical significance of serum ferritin in monitoring the iron status of patients on maintenance hemodialysis (MHD) has become suspected. In this review, we reassess the interpretation of high serum ferritin values in such patients, with the goal of treating their anemia in a safe way. From the observations that (1) $\mathrm{H}$-ferritin gene transcription is predominantly active in inflammatory conditions, whereas L-ferritin is induced only after exposure to very high iron concentrations and is preferentially secreted to plasma from hepatocytes; (2) the expression of both types of ferritin proteins are exclusively dependent on intracellular free iron, which is often sequestered by LPS or cytokines in several cell types, and (3) splenic iron is depleted and serum ferritin does not increase in the combined conditions of both inflammation and iron deficiency, it is deduced that elevated serum ferritin levels are caused by the accumulation of intracellular iron, especially reticuloendothelial cells or macrophages, hepatocytes, and other cells, while cytokines or inflammation might modulate the relative ratio of ferritin to body iron storage.
\end{abstract}

Therefore, high levels of serum ferritin in patients on MHD can be used to indicate iron deposition in most cells, including vascular and immunocompetent cells, and is still a reliable indicator of the need to withhold iron administration.

Copyright $\odot 2010$ S. Karger AG, Basel

\section{Background}

Routine monitoring of body iron stores is an essential component of the overall management of patients on maintenance hemodialysis (MHD). Maintaining adequate iron stores is important for the prevention of iron overload as well as for the treatment of iron deficiency [1]. Anemia of chronic disease (ACD), which is tightly linked to an insufficient iron supply for erythropoiesis, is often associated with reduced physical and mental function and poor quality of life [2]. Iron overload has also been suspected to be associated with a variety of complications, including infection and endothelial dysfunction [3].

Monitoring the iron status of patients with chronic kidney disease (CKD) only with conventional markers, such as serum ferritin and transferrin saturation, often leads to questionable results because of the frequent co-

\section{KARGER}

Fax +41613061234 E-Mail karger@karger.ch www.karger.com
(ㄷ) 2010 S. Karger AG, Basel

0250-8095/10/0325-0439\$26.00/0

Accessible online at:

www.karger.com/ajn
Takeshi Nakanishi, MD

Division of Nephrology and Dialysis, Department of Internal Medicine

Hyogo College of Medicine

1-1 Mukogawa-cho, Nishinomiya 6638501 (Japan)

Tel. +81 79845 6521, Fax +81 79845 6880, E-Mail t-nkns@hyo-med.ac.jp 

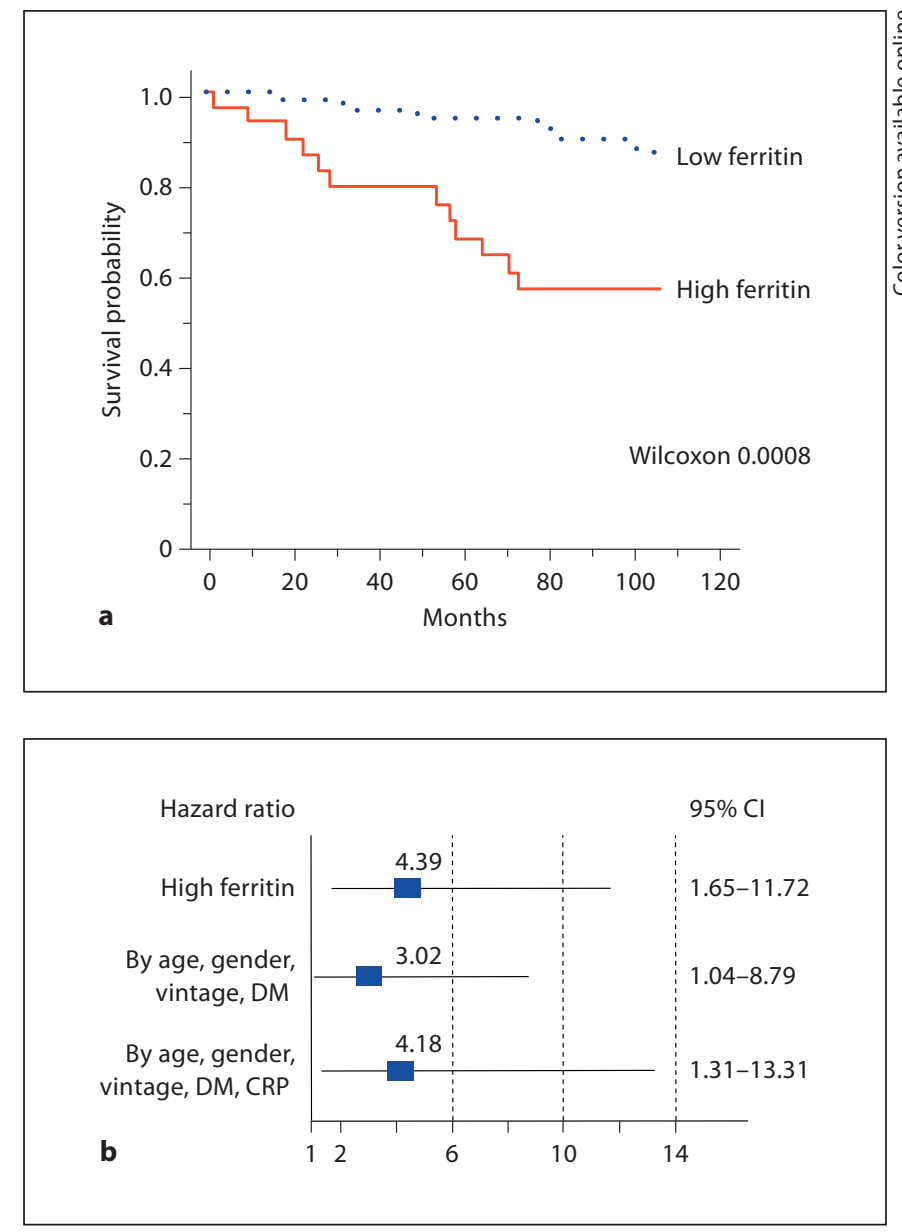

Fig. 1. Estimated cumulative incidence of all-cause death in the high-/low-ferritin groups. Ninety stable hemodialyzed patients were enrolled and followed for 107 months. a Kaplan-Meier analysis indicates time to all-cause death in the high-/low-ferritin groups. The solid line represents patients with ferritin $\geq 100 \mathrm{ng} /$ $\mathrm{ml}$ (high-ferritin group) and the dotted line represents those with $<100 \mathrm{ng} / \mathrm{ml}$ (low-ferritin group). b Cox proportional hazards model of high ferritin levels for death [15]. CI = Confidence interval; $\mathrm{DM}=$ diabetes mellitus; $\mathrm{CRP}=\mathrm{C}$-reactive protein.

existence of chronic inflammation, infection, and malnutrition. These comorbid conditions generally affect the commonly used indices of body iron stores. Therefore, any interpretation of a given serum ferritin level in CKD patients needs to take into account the possible role of factors other than the status of iron repletion $[1,4-8]$. Because of the influence of the malnutrition-inflammation complex syndrome [9], several authors have suggested abandoning the use of serum ferritin as an indicator of iron stores in patients on MHD. This has also led to the proposal that i.v. iron administration should not be with- held in the presence of elevated serum ferritin levels since this might deprive CKD patients with inflammation and/ or malnutrition of much-needed iron supplements $[1,7]$.

High serum ferritin levels have been suspected to be associated with increased rates and lengths of hospitalization [10]. Moreover, a recent rise in serum ferritin levels has been reported to represent a relative risk of imminent death in MHD patients [11]. An association with dialysis morbidity, including the risk of iron overload and infection, as reflected by a high serum ferritin level has also been reported [12-14]. We recently demonstrated that a relatively high level of serum ferritin $(\geq 100 \mathrm{ng} / \mathrm{ml})$ was associated with a poor prognosis after adjustment for several basic factors and C-reactive protein (hazard ratio 4.18) [15] (fig. 1). Another study demonstrated that circulating advanced oxidation protein products (AOPP) were correlated with an increase in intima-media thickness and the wall-to-lumen ratio of the common carotid artery of patients on MHD. Moreover, AOPP was also correlated with serum ferritin and the i.v. iron dose [16].

The purpose of this review is to reassess the interpretation of high serum ferritin values in such patients, with the goal of treating their anemia in an effective way. In particular, we would like to answer the following $2 \mathrm{im}$ portant questions based on previous experimental and clinical research: (1) Are serum ferritin levels in inflammatory conditions relatively independent of body iron stores? (2) Are higher serum ferritin levels suitable for estimating the amount of iron available for erythropoiesis or excessive iron storage?

\section{Structure and Function of Ferritin}

Ferritin is the major iron storage protein found in human tissues [17-19]. This protein has the capacity to sequester up to 4,500 atoms of iron in a ferrihydrite mineral core, and it stores iron that is not required for immediate metabolic needs $[19,20]$. It contains 24 subunits of 2 types, i.e. liver $(\mathrm{L})$ and heart $(\mathrm{H})$, with molecular weights of 19 and $21 \mathrm{kDa}$, respectively [17]. The H-subunit is thought to play a role in the rapid detoxification of iron due to its ferroxidase activity, which oxidizes iron to the $\mathrm{Fe}$ (III) form for deposition within the core, whereas the L-subunit facilitates iron nucleation, mineralization, and long-term iron storage $[17,20,21]$. In vivo, a specific cell type synthesizes a specific ratio of $\mathrm{H}$-ferritin and $\mathrm{L}$-ferritin protein subunits during differentiation; the H:L protein subunit ratio is usually stable, except during chronic iron overload or inflammation [22-24]. 


\section{Regulation of Ferritin}

Recently, several authors reviewed the regulatory factors of cellular ferritin although the activities of these factors can be complicated and hard to understand precisely $[18,21,25]$. The system is sensitive not only to iron availability but also to the oxidative status of the cell. In fact, ferritin can be viewed both as part of a group of iron regulatory proteins that include transferrin and the transferrin receptor (TfR) and as a member of the protein family that orchestrates the cellular defense against stress and inflammation, as outlined in several reviews [26-29]. These reviews focus on the molecular mechanisms and biological implications of ferritin regulation by cytokines, oxidants, oncogenes, growth factors, and other stimuli, as well as their relevance to the complex.

The present article focuses on the type of ferritin that is upregulated during inflammation, oxidative stress, or iron excess.

The synthesis of ferritin is posttranscriptionally regulated by cytoplasmic transacting factor iron regulatory protein 1 (IRP1). Ferritin transcripts contain a $5^{\prime}$ iron regulatory element. When iron is present in excess in the cell, the iron-sulfur cluster in IRP1 prevents IRP1 from interacting with the iron regulatory element, which mediates the translational activation of ferritin synthesis $[2$, 25]. This adaptive response is important for protecting cells from free iron toxicity.

An induction of L-ferritin gene transcription by iron only occurs after acute or chronic exposure to very high iron doses [22-24, 30]. High concentrations of iron lead to a significant increase in the L-ferritin mRNA level, with no change in the $\mathrm{H}$-ferritin mRNA level, as shown by microarray analyses; treatment with iron chelator deferoxamine decreases L-ferritin mRNA [31].

$\mathrm{H}$-ferritin gene transcription is regulated by cytokines and hormones as well as by oxidants and antioxidant response inducers. For example, hydrogen peroxide activates the murine $\mathrm{H}$-ferritin gene [26], and proinflammatory cytokines tumor necrosis factor (TNF)- $\alpha$ and interferon- $\gamma$ increase the amount of $\mathrm{H}$-ferritin mRNA but not L-ferritin mRNA [29].

The iron effect has been shown to be specific for the L-ferritin subunit, whereas the effects of inflammation, oxidative stress, and cytokines are specific for the $\mathrm{H}$-subunit. Although the specific function of $\mathrm{H}$-ferritin, i.e. ferroxidase activity, may contribute to detoxifying iron and reducing cellular iron availability in states of inflammation and oxidative stress, the mechanism of the differential regulation of $\mathrm{L}$-ferritin and $\mathrm{H}$-ferritin by iron and various stress situations is not known $[18,21]$. We would like to emphasize ferritin's role as an acute phase reactant that is affected by inflammation and oxidative stress, both of which appear to upregulate $\mathrm{H}$-ferritin preferentially over L-ferritin.

\section{Characteristics of Serum Ferritin}

Of the total ferritin in the human body, only small amounts are found in circulation. This plasma protein is a by-product of intracellular ferritin synthesis [18, 25]. Whereas tissue ferritins consist of variable proportions of $\mathrm{H}$ - and L-subunit types, serum ferritin contains only Lferritin and the glycosylated (G)-subunit, which are immunologically similar. The G-subunit, which is present only in extracellular ferritin, is probably the product of a posttranslational modification of the L-chain $[25,32]$.

Despite the widespread use of serum ferritin as a clinical indicator of body iron stores, little is known regarding the precise source of this ferritin. Recently, Ghosh et al. [33] examined the secretion of L-ferritin from human hepatocytes. Export of this protein occurs through the classical secretory pathway, and some chains are N-glycosylated. In addition, even when individual ferritin chains were overexpressed via adenovirus transduction, L-ferritin was secreted at high levels over a relatively short period of time, whereas $\mathrm{H}$-ferritin secretion was not observed. From these observations, it has been deduced that L-ferritin may be exclusively glycosylated and secreted to the extracellular space or plasma [33]. In conditions of inflammation or liver disease, however, we should be aware that the ratio of the glycosylated form to the nonglycosylated form in serum ferritin changes. Although the factors that determine the balance between the glycosylated and nonglycosylated forms remain to be explored, serum ferritin can also be greatly increased by damaged tissues, in which case most of the ferritin is nonglycosylated [12].

\section{Cytokines and Expression of Ferritin Protein}

Previous observations have demonstrated that intracellular iron is essential for the accelerated expression of ferritin, even in the extracellular environment of elevated cytokines. Rogers et al. [34] demonstrated that interleukin (IL)- $1 \beta$ induces $\mathrm{H}$-ferritin but not L-ferritin gene expression by modulating the transcription of its $\mathrm{mRNA}$ when added to the culture medium of human hepatoma 
Fig. 2. Iron and ferritin in polymorphonuclear leucocytes (PMNL) from patients on MHD. Seventeen MHD patients without apparent infection or malignancy as well as 17 controls were recruited. The serum ferritin level was higher while the serum iron concentration was lower in patients on MHD than in controls. PMNL ferritin and iron content was increased in MHD [40]. * $\mathrm{p}<0.05$ compared with controls; ${ }^{* *} \mathrm{p}<0.01$ compared with controls.
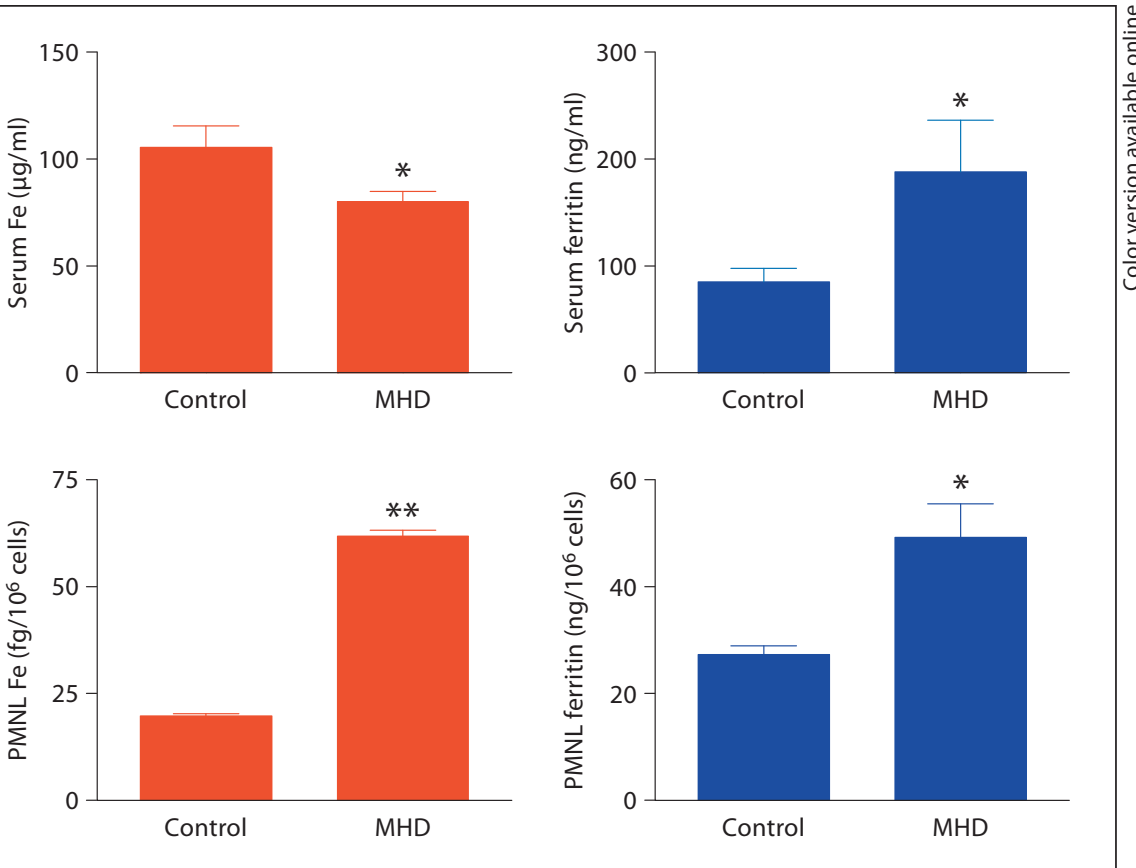

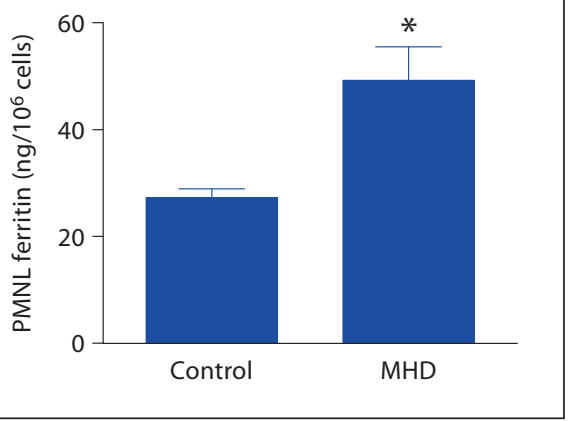

cells (HepG2). Remarkably, ferritin protein induction by this cytokine was totally dependent on cytoplasmic free iron as ferritin translation was inhibited by the action of the intracellular iron chelator deferoxamine.

The relationship between TNF- $\alpha$ and iron in regulating ferritin was examined by Miller et al. [35] using primary human myoblasts. TNF- $\alpha$ induced $\mathrm{H}$-ferritin mRNA independently of iron, but the complete induction of $\mathrm{H}$-ferritin translation required the presence of iron. No change in L-ferritin mRNA was observed under the same conditions. Thus, it has been confirmed that the presence of free iron is required for the translation of TNF- $\alpha$-induced $\mathrm{H}$-ferritin mRNA. These authors suspected that alterations in ferritin after TNF- $\alpha$ treatment resulted from a TNF- $\alpha$-mediated increase in intracellular iron [35].

In LPS-challenged mice, a small but significant elevation in liver iron concentrations was observed, with a concomitant suppression of the expression of the iron export protein ferroportin 1 (FPN1) [36]. The relationships between TNF- $\alpha$ and the expression of FPN1 mRNA in rat [37] and mouse hepatocytes [36] and human monocytic cells have been confirmed in other studies [38]. We have also demonstrated TNF- $\alpha$-induced iron sequestration in human umbilical vein endothelial cells, and iron accumulation in polymorphonuclear cells from the patients on MHD whose levels of IL- 6 and TNF- $\alpha$ were higher than those of healthy volunteers. In addition, iron sequestration in these cells was strongly associated with the reduction of the expression of iron export protein FPN1 and the induction of iron import proteins, TfR, and divalent metal transporter 1 (DMT1) [39, 40] (fig. 2). These observations suggested that a cytokine-induced reduction of iron export from several kinds of cells could cause iron sequestration in hepatocytes, reticuloendothelial cells, and other cells, which in turn might facilitate the expression of ferritin (fig. 3).

\section{Hepcidin and Ferritin}

Hepcidin is another regulator of the amount of iron retained within macrophages. Hepcidin is a 25 -amino acid peptide hormone synthesized primarily by hepatocytes and released into blood circulation. Upon reaching its target tissues, hepcidin binds to the iron exporter protein, i.e. FPN1, leading to the internalization and subsequent intracellular degradation of FPN1. Elevated levels, favoring macrophage iron retention, are encountered with increased iron intake, infection, and inflammation, which could be associated with ACD. Loss of the iron exporter function of FPN1 from macrophages leads to an intracellular retention of iron and to reduced extracellular serum iron levels [41]. 
We recently observed that, in the patients on MHD without apparent inflammation, serum hepcidin levels were exclusively associated with ferritin levels, independent of cytokines, IL- 6 , and TNF- $\alpha$ [42]. As there was no evidence of the correlation of expressions between hepcidin and ferritin in cultured cell models, it might be reasonable to presume that hepcidin-mediated iron retention in reticuloendothelial system (RES) cells and hepatocytes caused the increase in ferritin (fig. 3).

\section{Expression of Ferritin Protein in the Condition of Inflammation and/or Iron Deficiency}

Recently, Theurl et al. [43] made a significant observation regarding the expression of splenic ferritin in conditions of ACD and/or iron deficiency anemia (IDA). During inflammation, iron retention in macrophages and an elevation of ferritin protein in the spleen, but not in the liver, occurs. The coexistence of ACD and IDA dissipates the increase in the expression of splenic ferritin. Correspondingly, in humans suffering from ACD, serum ferritin concentrations are elevated but the coexistence of IDA significantly reduces serum ferritin (fig. 4). From these results, it should be stressed that if iron is depleted in the body serum ferritin fails to increase even in the condition of ACD [43]. These observations have also been confirmed in spleen from a murine model of chronic inflammation [44].

\section{Serum Ferritin Reflects Iron Storage}

From the observations that (1) H-ferritin gene transcription is predominantly active in inflammatory conditions, whereas L-ferritin is induced only after exposure to very high iron concentrations and is preferentially secreted to plasma from hepatocytes; (2) the expression of both types of ferritin proteins are exclusively dependent on intracellular free iron which is often sequestered by LPS, TNF- $\alpha$, or hepcidin in several cell types including hepatocytes [37], reticuloendothelial cells [38], human umbilical vein endothelial cells [39], and polymorphonuclear cells [40], and (3) in conditions of both inflammation and iron deficiency, splenic iron is depleted and serum ferritin does not increase, we may presume that elevated serum ferritin levels could be closely associated with a higher storage of iron while cytokines or inflammation might modulate the ratio of ferritin to body iron storage (fig. 5). Although the serum level of ferritin should reflect the to-

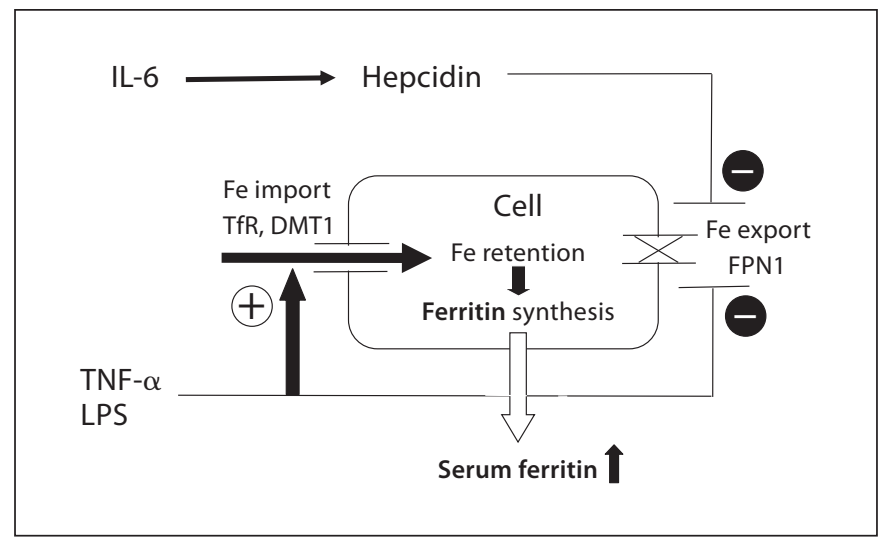

Fig. 3. Mechanism of iron sequestration in inflammation. TNF- $\alpha$ causes the upregulation of iron import proteins TfR and DMT1 and the downregulation of iron export protein FPN1. IL- 6 increases hepcidin, which induces the internalization and degradation of FPN1. Consequently, iron is sequestered in the cells, which facilitates ferritin synthesis.

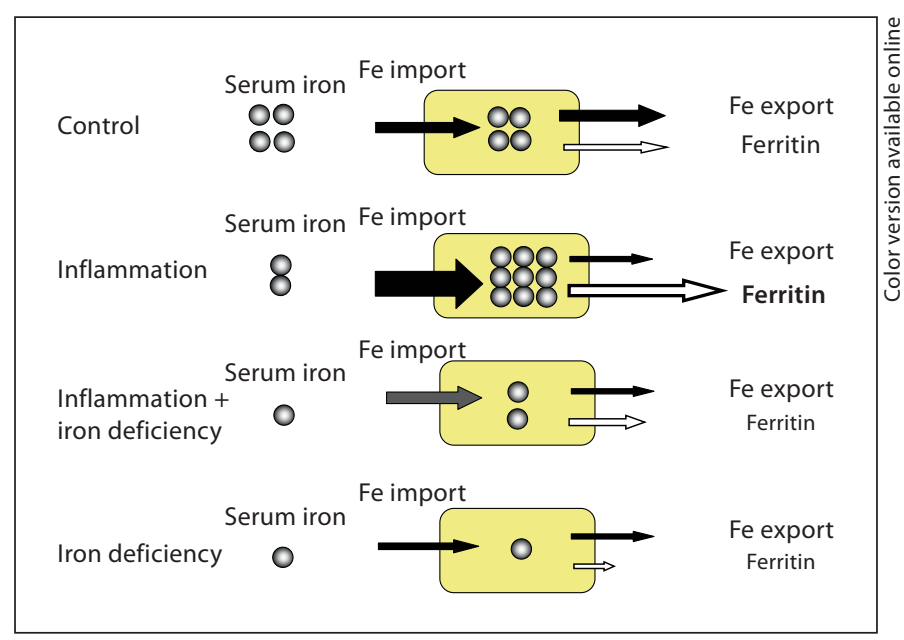

Fig. 4. Iron metabolism in anemia of inflammation, iron deficiency, and the combined state (inflammation + iron deficiency). In conditions of inflammation without iron deficiency, iron is retained in the cells (mainly reticuloendothelial cells and hepatocytes), which causes high serum ferritin. In the condition of the combined state between inflammation and iron deficiency, iron is not retained in the cells, which causes low serum ferritin.

tal amount of ferritin released from all organs and cells, reticuloendothelial cells or macrophages and hepatocytes are the 2 major sites of iron storage in humans. Consequently, both cell types are major contributors to the circulating ferritin pool $[19,45,46]$. Therefore, we can pre- 


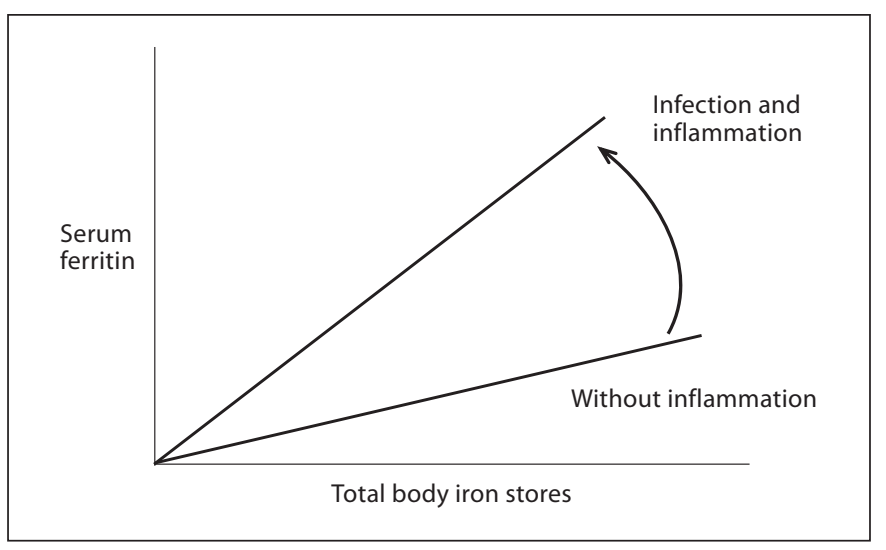

Fig. 5. Relationship between the total body iron store and the serum ferritin level: Infection and inflammation might increase the relative ratio of serum ferritin to iron storage.

sume that elevated serum ferritin levels indicate a state of iron overload in the liver and the spleen, although the serum ferritin level is not a particularly robust analytical tool and is likely to increase in conditions of hypercytokinemia by changing the sensitivity to cellular iron.

\section{Serum Ferritin and Iron Supplementation to Bone Marrow for Erythropoiesis}

In healthy individuals, the serum ferritin concentration is proportional to the total body iron stores, with a lower normal limit of $12 \mathrm{ng} / \mathrm{ml}$ predicting absolute iron deficiency $[19,47]$. Some healthy adults have serum ferritin values as high as $200 \mathrm{ng} / \mathrm{ml}$, but such high levels of serum ferritin may be associated with glucose intolerance or other comorbid conditions [48-51]. Patients on MHD generally have markedly higher serum ferritin levels than do normal individuals for any given level of iron stores. This could be reasonably explained by the fact that they carry an inflammatory burden with hypercytokinemia. In patients on MHD treated with erythropoiesis-stimulating agent (ESA) therapy, the 2006 guidelines of the National Kidney Foundation-Kidney Disease Outcome Quality Initiative (NKF-KDOQI) suggest that the lower limit of serum ferritin indicating absolute iron deficiency (i.e. depleted iron stores) is around $200 \mathrm{ng} / \mathrm{ml}$ [52]. The revised European Best Practice Guidelines (EBPG) of 2004 define iron deficiency as a serum ferritin level $<100$ $\mathrm{ng} / \mathrm{ml}$ and a transferrin saturation $<20 \%$ [47]. However, even with these threshold levels the provision of iron to the bone marrow may be deficient $[2,53]$. The observed discrepancies might be explained by a heterogeneous propensity to iron deposition between the bone marrow and the liver or spleen.

In an investigation on the distribution of stainable iron stores in various organs of 50 hemodialysis patients, there was an absence or scarcity of stainable iron in the bone marrow of the majority of patients [54]. In contrast, massive iron deposits in the liver and spleen, which are compatible with the diagnosis of advanced hepatosplenic siderosis, were observed. The authors of this study stressed that the iron accumulated in the liver and spleen was not in equilibrium with marrow iron and that it was not necessarily available for incorporation into hemoglobin. While marrow iron was readily accessible for erythropoiesis, that of other organs was either unavailable or only marginally available for this function. Although we should take into consideration that these studies were done in a pre-ESA era and that repeated transfusions may affect iron metabolism, we could presume that elevated serum ferritin levels in this setting are mainly associated with hepatosplenic siderosis, but this was not a practical way to exclude the possibility of bone marrow iron depletion $[54,55]$.

The principal reason for erythropoietin hyporesponsiveness is iron deficiency, which includes absolute iron deficiency and functional iron deficiency $[56,57]$. It has been repeatedly demonstrated that CKD patients with normal or even markedly increased serum ferritin levels can be functionally iron deficient [58]. After all, iron is not released fast enough from its stores in the RES to meet the increased demand for iron driven by ESA therapy [47, 56]. Thus, elevated serum ferritin levels do not guarantee a sufficient iron supply in response to the demand of bone marrow although serum ferritin levels are an accurate indicator of the amount of iron stored in the body, primarily in the hepatocytes or RES.

Therefore, it has been clear for many years that the amount of iron available for erythropoiesis cannot be evaluated solely on the basis of serum ferritin. However, a very high ferritin concentration probably is a reliable indicator of the need to withhold iron administration in MHD patients. Further clinical trials are necessary to establish the optimal treatment modality of renal anemia in such patients with hepatosplenic siderosis but no available iron in the bone marrow. 


\section{Conclusion}

The relationship of serum ferritin levels to body iron stores may be altered in inflammatory states and liver disease, conditions that can disproportionately elevate the levels of this circulating protein. Despite these drawbacks, serum ferritin is a good measure of the amount of iron stored in the body, primarily in the hepatocytes and RES. Elevated serum ferritin levels indicate iron overload, mainly in the form of hepatosplenic siderosis, but do not exclude the possibility of a depletion of bone mar- row iron stores and iron unavailablity for erythropoiesis due to a heterogeneous propensity for iron deposition between bone marrow and the liver or spleen. Therefore, high levels of serum ferritin in MHD patients without apparent inflammation may indicate iron deposition in the liver and spleen.

\section{Disclosure Statement}

The authors report no conflict of interest.

\section{References}

$\checkmark 1$ Coyne D: Iron indices: what do they really mean? Kidney Int Suppl 2006;101:S4-S8.

2 Weiss G: Iron metabolism in the anemia of chronic disease. Biochim Biophys Acta 2009; 1790:682-693.

- 3 Sengoelge G, Sunder-Plassmann G, Horl WH: Potential risk for infection and atherosclerosis due to iron therapy. J Ren Nutr 2005; 15:105-110.

4 Kalantar-Zadeh K, Luft FC, Humphreys MH: Moderately high serum ferritin concentration is not a sign of iron overload in dialysis patients. Kidney Int 1999;56:758-759.

5 Lee DH, Zacharski LR, Jacobs DR Jr: Comparison of the serum ferritin and percentage of transferrin saturation as exposure markers of iron-driven oxidative stress-related disease outcomes. Am Heart J 2006;151: 1247.e1-1247.e7.

-6 Agarwal R: Overcoming barriers that inhibit proper treatment of anemia. Kidney Int Suppl 2006;101:S9-S12.

7 Besarab A: Resolving the paradigm crisis in intravenous iron and erythropoietin management. Kidney Int Suppl 2006;101:S13S18.

8 Kalantar-Zadeh K, Kalantar-Zadeh K, Lee $\mathrm{GH}$ : The fascinating but deceptive ferritin: to measure it or not to measure it in chronic kidney disease? Clin J Am Soc Nephrol 2006; 1:S9-S18.

-9 Kalantar-Zadeh K, Rodriguez RA, Humphreys MH: Association between serum ferritin and measures of inflammation, nutrition and iron in haemodialysis patients. Nephrol Dial Transplant 2004;19:141-149.

10 Kletzmayr J, Horl WH: Iron overload and cardiovascular complications in dialysis patients. Nephrol Dial Transplant 2002;17(suppl 2):25-29.

11 Kalantar-Zadeh K, Don BR, Rodriguez RA, Humphreys MH: Serum ferritin is a marker of morbidity and mortality in hemodialysis patients. Am J Kidney Dis 2001;37:564-572.
12 Eschbach JW, Adamson JW: Iron overload in renal failure patients changes since the introduction of erythropoietin therapy. Kidney Int Suppl 1999;69:S35-S43.

13 Yuan XM, Li W: The iron hypothesis of atherosclerosis and its clinical impact. Ann Med 2003;35:578-591.

14 Jenq CC, Hsu CW, Huang WH, Chen KH, Lin JL, Lin-Tan DT: Serum ferritin levels predict all-cause and infection-cause 1-year mortality in diabetic patients on maintenance hemodialysis. Am J Med Sci 2009;337: 188-194.

15 Hasuike Y, Nonoguchi H, Tokuyama M, Ohue M, Nagai T, Yahiro M, Nanami M, Otaki Y, Nakanishi T: Serum ferritin predicts prognosis in hemodialysis patients: the Nishinomiya study. Clin Exp Nephrol 2010; 14:349-355.

16 Drueke T, Witko-Sarsat V, Massy Z, Descamps-Latscha B, Guerin AP, Marchais SJ, Gausson V, London GM: Iron therapy, advanced oxidation protein products, and carotid artery intima-media thickness in endstage renal disease. Circulation 2002;106: 2212-2217.

17 Harrison PM, Arosio P: The ferritins: molecular properties, iron storage function and cellular regulation. Biochim Biophys Acta 1996;1275:161-203.

18 Hintze KJ, Theil EC: Cellular regulation and molecular interactions of the ferritins. Cell Mol Life Sci 2006;63:591-600.

19 Cavill I: Iron status as measured by serum ferritin the marker and its limitations. Am J Kidney Dis 1999;34(suppl 2):12-17.

20 Rucker P, Torti FM, Torti SV: Role of $\mathrm{H}$ and L subunits in mouse ferritin. J Biol Chem 1996;271:33352-33357.

21 Theil EC: Ferritin at the crossroads of iron and oxygen metabolism. J Nutr 2003; 133(suppl 1):1549S-1553S.
22 Dickey LF, Sreedharan S, Theil EC, Didsbury JR, Wang YH, Kaufman RE: Differences in the regulation of messenger RNA for housekeeping and specialized-cell ferritin: a comparison of three distinct ferritin complementary DNAs, the corresponding subunits, and identification of the first processed in amphibia. J Biol Chem 1987;262:7901-7907.

23 White K, Munro HN: Induction of ferritin subunit synthesis by iron is regulated at both the transcriptional and translational levels. J Biol Chem 1988;263:8938-8943.

24 Leggett BA, Fletcher LM, Ramm GA, Powell LW, Halliday JW: Differential regulation of ferritin $\mathrm{H}$ and $\mathrm{L}$ subunit mRNA during inflammation and long-term iron overload. J Gastroenterol Hepatol 1993;8:21-27.

25 Torti FM, Torti SV: Regulation of ferritin genes and protein. Blood 2002;99:35053516.

26 Tsuji Y, Ayaki H, Whitman SP, Morrow CS, Torti SV, Torti FM: Coordinate transcriptional and translational regulation of ferritin in response to oxidative stress. Mol Cell Biol 2000;20:5818-5827.

27 Orino K, Lehman L, Tsuji Y, Ayaki H, Torti SV, Torti FM: Ferritin and the response to oxidative stress. Biochem J 2001;357:241247.

28 Torti SV, Kwak EL, Miller SC, Miller LL, Ringold GM, Myambo KB, Young AP, Torti FM: The molecular cloning and characterization of murine ferritin heavy chain, a tumor necrosis factor-inducible gene. J Biol Chem 1988;263:12638-12644.

29 Fahmy M, Young SP: Modulation of iron metabolism in monocyte cell line U937 by inflammatory cytokines changes in transferrin uptake, iron handling and ferritin mRNA. Biochem J 1993;296(pt 1):175-181.

30 Cairo G, Bardella L, Schiaffonati L, Arosio P, Levi S, Bernelli-Zazzera A: Multiple mechanisms of iron-induced ferritin synthesis in HeLa cells. Biochem Biophys Res Commun 1985;133:314-321. 
-31 Muckenthaler M, Richter A, Gunkel N, Riedel D, Polycarpou-Schwarz M, Hentze S, Falkenhahn M, Stremmel W, Ansorge W, Hentze MW: Relationships and distinctions in iron-regulatory networks responding to interrelated signals. Blood 2003;101:36903698.

32 Cragg SJ, Wagstaff M, Worwood M: Detection of a glycosylated subunit in human serum ferritin. Biochem J 1981;199:565-570.

33 Ghosh S, Hevi S, Chuck SL: Regulated secretion of glycosylated human ferritin from hepatocytes. Blood 2004;103:2369-2376.

- 34 Rogers JT, Bridges KR, Durmowicz GP, Glass J, Auron PE, Munro HN: Translational control during the acute phase response: ferritin synthesis in response to interleukin-1. J Biol Chem 1990;265:14572-14578.

- 35 Miller LL, Miller SC, Torti SV, Tsuji Y, Torti FM: Iron-independent induction of ferritin $\mathrm{H}$ chain by tumor necrosis factor. Proc Natl Acad Sci USA 1991;88:4946-4950.

36 Constante M, Jiang W, Wang D, Raymond VA, Bilodeau M, Santos MM: Distinct requirements for Hfe in basal and induced hepcidin levels in iron overload and inflammation. Am J Physiol Gastrointest Liver Physiol 2006;291:G229-G237.

- 37 Dzikaite V, Holmstrom P, Stal P, Eckes K, Hagen K, Eggertsen G, Gafvels M, Melefors O, Hultcrantz R: Regulatory effects of tumor necrosis factor-alpha and interleukin- 6 on HAMP expression in iron loaded rat hepatocytes. J Hepatol 2006;44:544-551.

- 38 Ludwiczek S, Aigner E, Theurl I, Weiss G: Cytokine-mediated regulation of iron transport in human monocytic cells. Blood 2003; 101:4148-4154.

- 39 Nanami M, Ookawara T, Otaki Y, Ito K, Moriguchi R, Miyagawa K, Hasuike Y, Izumi M, Eguchi H, Suzuki K, Nakanishi T: Tumor necrosis factor-alpha-induced iron sequestration and oxidative stress in human endothelial cells. Arterioscler Thromb Vasc Biol 2005;25:2495-2501.
40 Otaki Y, Nakanishi T, Hasuike Y, Moriguchi R, Nanami M, Hama Y, Izumi M, Takamitsu Y: Defective regulation of iron transporters leading to iron excess in the polymorphonuclear leukocytes of patients on maintenance hemodialysis. Am J Kidney Dis 2004;43: 1030-1039.

41 Babitt JL, Lin HY: Molecular mechanisms of hepcidin regulation: implications for the anemia of CKD. Am J Kidney Dis 2010;55: 726-741

42 Kuragano T, Shimonaka Y, Kida A, Furuta M, Nanami M, Otaki Y, Hasuike Y, Nonoguchi H, Nakanishi T: Determinants of hepcidin in patients on maintenance hemodialysis: role of inflammation. Am J Nephrol 2010;31:534-540.

43 Theurl I, Aigner E, Theurl M, Nairz M, Seifert M, Schroll A, Sonnweber T, Eberwein L, Witcher DR, Murphy AT, Wroblewski VJ, Wurz E, Datz C, Weiss G: Regulation of iron homeostasis in anemia of chronic disease and iron deficiency anemia: diagnostic and therapeutic implications. Blood 2009;113: 5277-5286.

44 Schümann K, Herbach N, Kerling C, Seifert M, Fillebeen C, Prysch I, Reich J, Weiss G, Pantopoulos K: Iron absorption and distribution in TNF(DeltaARE/+) mice, a model of chronic inflammation. J Trace Elem Med Biol 2010;24:58-66.

45 Papanastasiou DA, Vayenas DV, Vassilopoulos A, Repanti M: Concentration of iron and distribution of iron and transferrin after experimental iron overload in rat tissues in vivo: study of the liver, the spleen, the central nervous system and other organs. Pathol Res Pract 2000;196:47-54.

46 Arosio P, Levi S: Ferritin, iron homeostasis, and oxidative damage. Free Radic Biol Med 2002;33:457-463.

47 Fishbane S, Maesaka JK: Iron management in end-stage renal disease. Am J Kidney Dis 1997;29:319-333.

-48 Fumeron F, Pean F, Driss F, Balkau B, Tichet J, Marre M, Grandchamp B: Ferritin and transferrin are both predictive of the onset of hyperglycemia in men and women over 3 years: the data from an epidemiological study on the Insulin Resistance Syndrome (DESIR) study. Diabetes Care 2006;29:20902094.
-49 Jiang R, Manson JE, Meigs JB, Ma J, Rifai N, $\mathrm{Hu}$ FB: Body iron stores in relation to risk of type 2 diabetes in apparently healthy women. JAMA 2004;291:711-717.

50 Mendler MH, Turlin B, Moirand R, Jouanolle AM, Sapey T, Guyader D, Le Gall JY, Brissot $\mathrm{P}$, David V, Deugnier Y: Insulin resistance-associated hepatic iron overload. Gastroenterology 1999;117:1155-1163.

51 Vari IS, Balkau B, Kettaneh A, Andre P, Tichet J, Fumeron F, Caces E, Marre M, Grandchamp B, Ducimetiere P; DESIR Study Group: Ferritin and transferrin are associated with metabolic syndrome abnormalities and their change over time in a general population: Data from an Epidemiological Study on the Insulin Resistance Syndrome (DESIR). Diabetes Care 2007;30: 1795-1801.

52 Kidney Disease Outcomes Quality Initiative clinical practice guidelines and clinical practice recommendations for anemia in chronic kidney disease: using iron agents. Am J Kidney Dis 2006;47:S58-S70.

53 Gotloib L, Silverberg D, Fudin R, Shostak A: Iron deficiency is a common cause of anemia in chronic kidney disease and can often be corrected with intravenous iron. J Nephrol 2006;19:161-167.

54 Ali M, Fayemi AO, Rigolosi R, Frascino J, Marsden T, Malcolm D: Hemosiderosis in hemodialysis patients: an autopsy study of 50 cases. JAMA 1980;244:343-345.

$\checkmark 55$ Ali M, Rigolosi R, Fayemi AO, Braun EV, Frascino J, Singer R: Failure of serum ferritin levels to predict bone-marrow iron content after intravenous iron-dextran therapy. Lancet 1982;1:652-655.

56 Fishbane S, Kowalski EA, Imbriano LJ, Maesaka JK: The evaluation of iron status in hemodialysis patients. J Am Soc Nephrol 1996; 7:2654-2657.

57 Nissenson AR: Achieving target hematocrit in dialysis patients new concepts in iron management. Am J Kidney Dis 1997;30:907911.

58 Weiss G, Goodnough LT: Anemia of chronic disease. N Engl J Med 2005;352:1011-1123. 